NASZA DERMATOLOGIA Online OUR DERMATOLOGY Online

Source of Support: Nil

Competing Interests None

\section{LAPTOP-INDUCED ERYTHEMA AB IGNE - A CASE REPORT}

\author{
Cesar Bimbi ${ }^{1}$, Piotr Brzezinski ${ }^{2}$ \\ ${ }^{\prime}$ Member of Dermatological Comittee of State Medical Council of Rio Grande do Sul \\ Brazil, Brazilian Society of Dermatology \\ ${ }^{2}$ Department of Dermatology, 6th Military Support Unit, Ustka, Poland
}

Corresponding author: Dr. Cesar Bimbi

cbimbi@,terra.com.br

\section{Introduction}

Erythema ab igne is now more commonly related to heating pads, water bottles, infrared lamps and laptop computer use with skin contact. Heat damages superficial skin vessels leading to vasodilatation and leakage of blood and deposition of hemosiderin that presents in a net form. Any surface of the body is susceptible but mostly lower limbs, lower back and abdomen areas are affected.

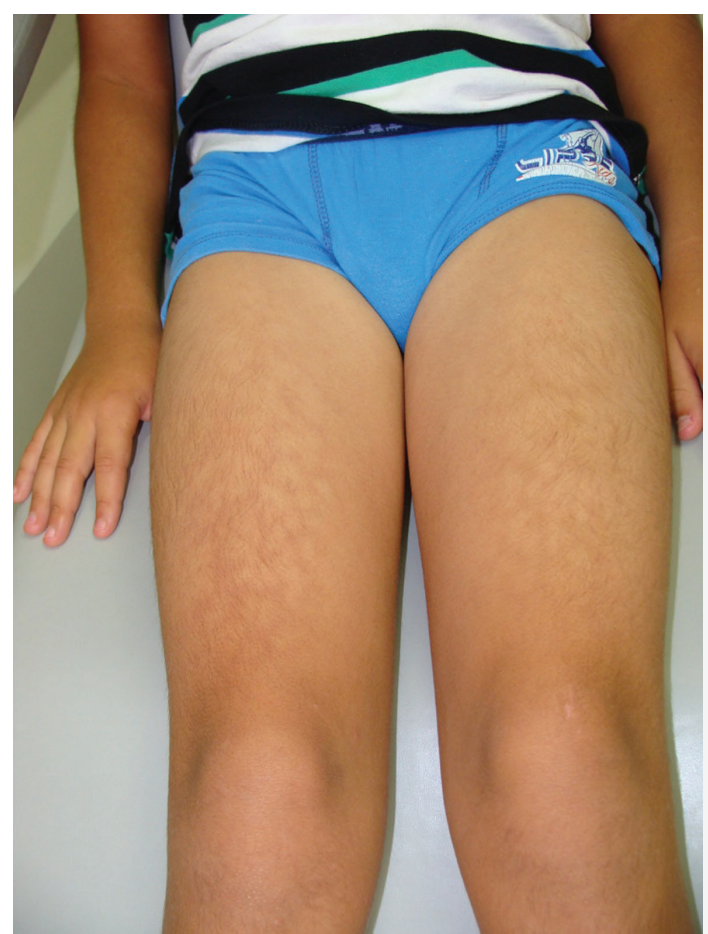

Figure 1. Dirty appearing eruption of reticulate violaceous brown patch on anterior thighs.

\section{Case Report}

A 8-year-old boy presented with a four month history of dark brown pigmentation only to the anterior aspects of right and left thighs, symetrically (Fig 1). The distribution was reticular, the lesions were not blanchable and there were no symptoms.

There was no need of biopsy since clinical diagnosis of erythema ab igne was obvious.

His mother mentioned the fact of him using laptop positioned atop thighs (Fig. 2). Using his anterior thighs to prop up his laptop - and she added the fact that he used to work on his computer in that position several hours and every day.

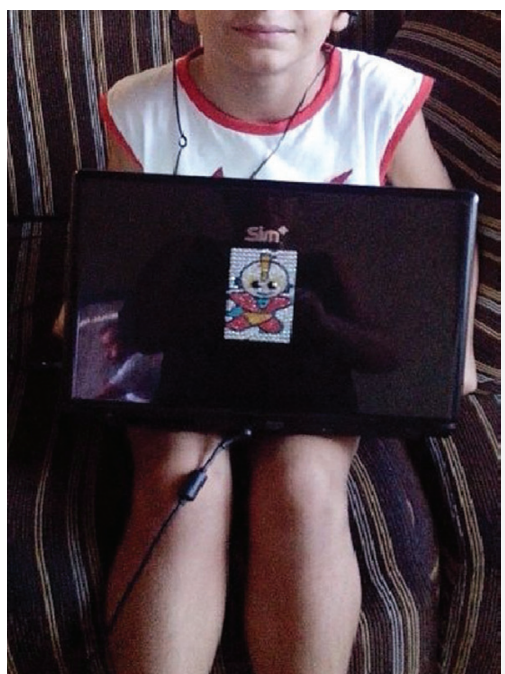

Figure 1. Laptop positioned atop thighs in a 8-year-old boy. 


\section{Discussion}

Erythema $a b$ igne is rare and not commonly seen on daily practice. It was once related to standing long periods of time in front of open fires or stoves to warm the body or using water bottles or heating pads for chronic backache. With introduction of heating systems it turned out to be a rare condition at least in developed countries. Bakers and foundrymen are at occupational risk. Heat damages superficial skin vessels leading to vasodilatation and leakage of blood with deposition of hemosiderin that presents in a net form [1]. It is very characteristic and one of those clinical features that deserves dermatologycal saying that "once seeing, never forgotten". Nevertheless, Livedo Reticularis [2] can be a point of confusion but then the changes are to be strictly symetrical and telangiectatic.

Laptop use is a modern inducer of this reaction $[3,4]$. Concentrated infrared radiation at the bottom of the laptop heats the skin only

not enough to burn it but sufficient to affect skin superficial vessels. With the passage of time, the repeated heating leads to Erythema ab igne $[5,6]$.

Always good to keep in mind that heat damage has been also associated with skin cancer and Merkel carcinoma. There may be epithelial cellular atypia resembling actinic damage, and some cases eventually go to thermal keratosis and squamous cell carcinomas $[7,8]$.

Educate patients on avoiding prolonged laptop to thigh contact is essential. With removal of the heat source from the skin, no further treatment is required.

The skin changes usually clear spontaneously in several weeks to months, if the repeated exposure to heat is discontinued.

\section{REFERENCES}

1. Poustinchian BR, Pohlman DJ. Erythema ab igne. J Am Osteopath Assoc. 2012;112:808.

2. Riahi R, Cohen P, Robinson F, Gray J. Erythema ab igne mimicking livedo reticularis. Int J Dermatol. 2010;49:1314-7.

3. Billic M, Adams BB. Erythema ab igne induced by a laptop computer. J Am Acad Dermatol. 2004;50:973-4.

4. Erythema ab igne caused by laptop computer gaming--a case report. (English) By: Fu LW; Vender R, International Journal Of Dermatology [Int J Dermatol], ISSN: 1365-4632, 2012 Jun; Vol. 51 (6), pp. 716-7; Publisher: Blackwell Science; PMID: 22607292

5. Botten D, Langley R, Webb A. Academic branding: erythema $\mathrm{ab}$ igne and use of laptop computers. Canadian Med Assoc J. 2010;182:E857.

6. Bachmeyer C, Bensaid P, Bégon E. Laptop computer as a modern cause of erythema ab igne. J Eur Acad Dermatol Venereol. 2009;23:736-73.

7. Brzezinski P, Ismail S, Chiriac A. Radiator-induced erythema ab igne in 8-years-old girl. Rev Chil Pediatr. 2014;85:239-41.

8. Hewitt JB, Sherif A, Kerr KM, Stankler L. Merkel cell and squamous cell carcinomas arising in erythema ab igne. Br J Dermatol. 1993;128:591-2.

Copyright by Cesar Bimbi, et al. This is an open access article distributed under the terms of the Creative Commons Attribution License, which permits unrestricted use, distribution, and reproduction in any medium, provided the original author and source are credited. 